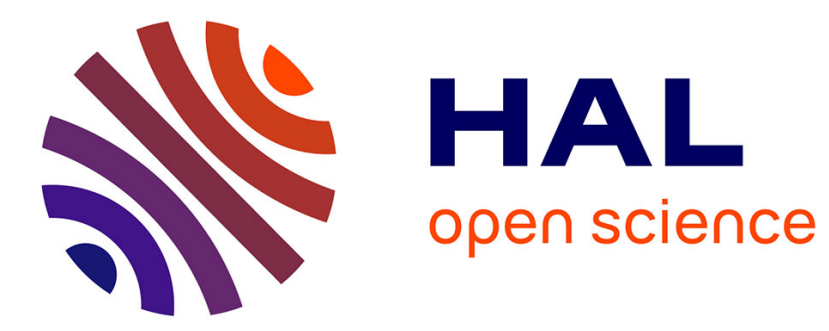

\title{
Nesting biology of two species of Megachile (Moureapis) (Hymenoptera: Megachilidae) in a semideciduous forest reserve in southeastern Brazil
}

Carolina Cardoso, Fernando Silveira

\section{- To cite this version:}

Carolina Cardoso, Fernando Silveira. Nesting biology of two species of Megachile (Moureapis) (Hymenoptera: Megachilidae) in a semideciduous forest reserve in southeastern Brazil. Apidologie, 2011, 43 (1), pp.71-81. 10.1007/s13592-011-0091-z . hal-01003630

\section{HAL Id: hal-01003630 \\ https://hal.science/hal-01003630}

Submitted on 1 Jan 2011

HAL is a multi-disciplinary open access archive for the deposit and dissemination of scientific research documents, whether they are published or not. The documents may come from teaching and research institutions in France or abroad, or from public or private research centers.
L'archive ouverte pluridisciplinaire HAL, est destinée au dépôt et à la diffusion de documents scientifiques de niveau recherche, publiés ou non, émanant des établissements d'enseignement et de recherche français ou étrangers, des laboratoires publics ou privés. 


\title{
Nesting biology of two species of Megachile (Moureapis) (Hymenoptera: Megachilidae) in a semideciduous forest reserve in southeastern Brazil
}

\author{
Carolina F. CARdoso, Fernando A. Silveira \\ Laboratório de Sistemática e Ecologia de Abelhas, Departamento de Zoologia, Instituto de Ciências Biológicas, \\ Universidade Federal de Minas Gerais, Caixa postal 486, CEP: 30.123-970, Belo Horizonte, MG, Brazil
}

Received 27 October 2010 - Revised 20 June 2011 - Accepted 11 July 2011

\begin{abstract}
Nests of Megachile (Moureapis) benigna and Megachile (Moureapis) maculata were obtained during a 12-month trap-nesting program in a semideciduous forest reserve in southeastern Brazil. Trap nests were bamboo culms wider than those usually used in trap-nesting studies and it is suggested that species of Moureapis may prefer to nest in wide cavities. Nest construction was concentrated in the warm rainy season, but $M$. benigna had a secondary peak of nesting activity in the mid dry season, suggesting it is a bivoltine species. No species occupied the entire length of trap nests, but several linear series of cells were frequently packed inside a single culm. Nests of M. benigna were parasitized by one unidentified species of Coelioxys. Unidentified chalcidoid wasps emerged from some nests and phorid flies emerged from another one. In both cases, the developing host bees were killed. An unidentified conopid fly emerged from an adult female $M$. maculata found dead inside an incomplete nest.
\end{abstract}

Atlantic forest / wild bees / bionomy / nest materials / trap nests

\section{INTRODUCTION}

Species of Megachile (Megachilidae) occur practically all over the world and are widespread in Brazil where the genus is represented by 161 species (Silveira et al. 2002). Females of most species in the genus use leaf pieces (sometimes flower petals) to build their nests (e.g., Michener 1953, 2007; Krombein 1967) in pre-existing cavities, such as slits in rocks or burrows in the ground, dead wood, or man-made objects (Michener 2007). However, Eickwort et al. (1981) suggested that excavation of nests in the soil by female Megachile may be much more common than once supposed.

Corresponding author: F.A. Silveira, fernando@icb.ufmg.br

Manuscript editor: Stan Schneider
Although their nests are usually inconspicuous in the wild, studying Megachile nesting biology is facilitated because females of many of their species readily accept trap nests made of drilled wooden blocks or bamboo culms (e.g., Krombein 1967; Laroca 1971; Strickler et al. 1996; PittsSinger and Cane 2011). Although Megachile nesting ecology has been reasonably well studied in Europe and North America (e.g., Michener 1953; Hobbs and Lilly 1954; Krombein 1967; Richards 1978; Eickwort et al. 1981; Raw 1984, 1988; Williams et al. 1986; Cane et al. 1996; Barthell et al. 1998; Kemp and Bosch 2000; Armbrust 2004; Jenkins and Matthews 2004; Pitts-Singer and Cane 2011), it has been poorly investigated in Brazil with few works published, frequently with only incomplete information (von Ihering 1904; Laroca 1971, 1987; Blochtein and Wittmann 1988; Martins and Almeida 1994; 
Almeida et al. 1997; Zillikens and Steiner 2004). For the subgenus Moureapis, only fragmentary information is available on nests of a single species (Megachile apicipennis Schrottky, 1902) (von Ihering 1904; Laroca 1991). Moreover, Buschini et al. (2009) made a study of the pollen deposited in 16 nests of an unidentified species of this subgenus.

Although countless parasites attack nests of bees (e.g., Krombein 1967), knowledge on the infestation of neotropical species is scarce (Genaro 1996). Several insect groups have been recorded in association with nests of Megachile. Among the most common are the cleptoparasitic bees of the genus Coelioxys (Megachilidae, Megachilini; e.g., Michener 1953; Krombein 1967; Blochtein and Wittmann 1988; Yanega 1994; Krombein and Norden 1995; Scott et al. 2000; Morato 2003; Zillikens and Steiner 2004) and chalcidoid wasps (Chalcidoidea; Peck 1969). Moreover, some species of Diptera (e.g., Conopidae) have been recorded as parasitoids of adults (e.g., Krombein 1967; Doroshina 1991).

Nests and some aspects of the nesting biology of two species of Megachile (Moureapis) Raw, 2002 obtained in trap nests are described here as a contribution to the knowledge of the neotropical species of this subgenus.

\section{MATERIALS AND METHODS}

Data were collected at the Reserva Particular do Patrimônio Natural "Estação Ambiental de Peti" (Private Reserve of Natural Heritage "Peti Environmental Station"; from now on, "Peti"), which is a semideciduous forest reserve owned by the Minas Gerais State Energy Company (CEMIG). The 605-ha reserve is at $19^{\circ} 53^{\prime} 57^{\prime \prime} \mathrm{S}, 43^{\circ} 22^{\prime} 07^{\prime \prime} \mathrm{W}$, between 630 and $806 \mathrm{~m}$ elevation, in the municipalities of Santa Bárbara and São Gonçalo do Rio Abaixo in the state of Minas Gerais, Brazil. Regional climate according to Köppen's classification is the subtropical moderately humid with an annual average temperature of $21.7^{\circ} \mathrm{C}$ (Köppen in Peel et al. 2007). Local vegetation is mostly composed of secondary forest in various regeneration stages. Otherwise, there are small tracts of cerrado (Brazilian savanna), rocky fields (on mountain tops), and gardens with exotic species.
Trap nests were hollow bamboo culms with one open end. Originally intended to collect euglossine nests (Hymenoptera: Apidae: Euglossina), they were about $21 \mathrm{~cm}$ long, with diameters varying between 1.5 and $3.5 \mathrm{~cm}$, wider than generally used in trap-nesting studies. Bundles with six culms situated horizontally were tied to tree trunks, about $1.5 \mathrm{~m}$ above the soil surface, three facing one arbitrarily chosen direction and three facing the opposite direction. These bundles were set at $10-\mathrm{m}$ intervals along three trails inside the forest.

Because no direct observation could be made to verify that cells within a single bamboo culm were constructed by the same females, from here on, a single row of cells will be called a "cell series", and "trap nest" will refer to a single bamboo culm, which thus may contain several cell series of a single female or represent a multiple nest used by different females.

A total of 276 trap nests were kept in the field between May 2002 and May 2003. They were inspected monthly starting in June 2002. Culms occupied by bee nests were collected and taken to the laboratory. New empty culms were used to replace those collected. Culms occupied by termite or ant nests were cleaned and left in the bundles. When a female bee was observed actively nesting, the culm she was using was left in the field until the next inspection in the following month. In November, the trap nests were not inspected.

In the laboratory, culms brought from the field were open longitudinally and each cell series found inside was kept in a glass assay tube plugged with a cotton wad. The nests were examined daily for emergence, except on weekends. All insects emerging from the nests were killed with acetyl acetate and pinned. They were identified and deposited with their nest material in the Entomological Collection of the Taxonomic Collections of the Universidade Federal de Minas Gerais.

After emergence of the bees, the cell series were dissected. The material employed in the construction of the outer leaf layer (see below) of a sample of 10 cell series for Megachile benigna and three cell series for Megachile maculata was analyzed and classified as: (1) an entire leaf or leaflet, which had a central vein and only its basis cut by the bee; or (2) a leaf 
piece, which had no central vein and usually had all borders cut. Anatomical characteristics of the nesting material were evaluated to distinguish between leaf and petal fragments. The material used by each species in constructing the inner layer of the cells (see below) could not be verified.

The number of cell series per trap nest and the number of cells per cell series were counted and the internal diameter of the trap nests was measured to the nearest millimeter. Sex ratios were estimated for each species as the number of emerged females per emerged male. The $\chi^{2}$ test was applied to test whether those ratios differed from 1:1. Statistical analyses were made using BioEstat 4.0 (Ayres et al. 2005).

Two mortality types were considered in this study, according to Bosch and Kemp (2001) - (a) mortality due to other organisms (e.g., parasites, predators, and pathogens) and (b) other mortality events related, for example, to mechanical damage, inadequate temperature, and/or humidity conditions and inadequate food supply. This may be difficult to differentiate from mortality caused by microorganisms (e.g., bacteria and fungi). Mortality rates (\%) were calculated in relation to the total number of finished cells for each Megachile species.

\section{RESULTS}

Nests of four species of Megachile were obtained during the 12-month sampling period. Here, the nests and some bionomic aspects of two of them, M. benigna Mitchell, 1930 and $M$. maculata Smith, 1853 are presented. Both species belong in the subgenus Moureapis Raw, 2002, the latter one being frequently referred to in the literature as Megachile anthidioides Radoszkowski, 1874. A total of 95 specimens of these two species were obtained from 33 nests. The total number of specimens, of females and males that emerged, and the sex ratios are presented in Table I. The most abundant of the species was $M$. benigna with almost $95 \%$ of the bees emerged. All five specimens obtained of $M$. maculata were females but for $M$. benigna, the sex ratio obtained (1.2 females per male) did not differ significantly from 1:1 (Table I).
Table I. Number of emerged specimens of the two species of Megachile (Moureapis) obtained in trap nests in the RPPN Estação Ambiental de Peti (Minas Gerais, Brazil).

\begin{tabular}{lcccc}
\hline Species & $n$ & $\uparrow$ & $\widehat{\jmath}$ & $\mathrm{sr}$ \\
\hline M. (Moureapis) benigna & 90 & 49 & 41 & 1.20 \\
M. (Moureapis) maculata & 5 & 5 & 0 & -
\end{tabular}

$n$ total, $q$ number of females, and $\hat{\sigma}$ number of males obtained in all cell series, $s r$ sex ratio

\subsection{Nest architecture and nesting activity}

The cells of both species were always located at the inner end of the culms, leaving a long empty space between the last cell constructed and the entrance of the trap nests. However, two or more cell series were frequently packed inside a single culm (Figure 1). In almost all cases, only bees from the same species emerged from these multiple cell series. Only in two instances, individuals of different species emerged from the same trap nest. One case involved M. begnina and M. maculata and the other, M. benigna and M. (Chrysosarus) sp.

Females of $M$. benigna occupied 13 trap nests, constructing an average of 8.3 cell series per trap nest and 3.6 cells per cell series, while females of $M$. maculata occupied two trap nests, constructing an average of four cell series per trap nests and 2.7 cells per cell series (Table II).

The cell series obtained were structured as commonly described for Megachile and included two-layered cells positioned head to tail. The inner layer of the cells of both species was constructed with leaf pieces tightly stuck together (il in Figure 2). The outer layer is a cup of leaf pieces or, sometimes, entire leaves or leaflets (Table III) loosely arranged, one partially inserted into the one behind it (ol in Figure 2). Anatomical characteristics revealed that all cell series examined (of both species) were constructed only with leaves and had no flower petal fragments.

The numbers of finished, unfinished, and empty cells in the nests of the two species are shown in Table IV. An empty cell, with remains 


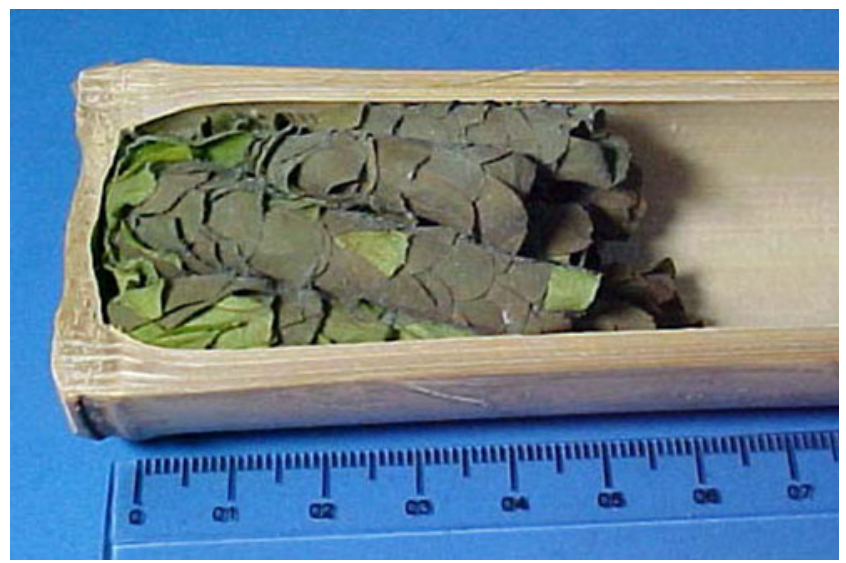

Figure 1. Bottom of a trap nest containing several cell series of Megachile (Moureapis) benigna. Smallest unit on the scale is equal to $1 \mathrm{~mm}$.

of a cap but with no vestige of provision, was found in a cell series of M. maculata. This series contained four cells, but bees emerged from only three of them. It is assumed that the empty cell, which was the last one and nearest to the trap nest entrance, was capped without food provision and that it was opened by the first bee to emerge from a cell behind it.

The nesting activity was mostly concentrated in the rainy season (Figure 3) but the nesting of $M$. benigna was extended, presenting two activity peaks - the main one $(53.3 \%$ of the cell series) in December and January (coinciding with the activity of $M$. maculata) and a secondary one in mid-August $(26.7 \%$ of the cell series). It should be remembered that part of the cell series recorded in December might have actually been constructed in November when no nest inspection was done in the field.

\subsection{Nest associates and bee mortality}

Several nest associates were found in the nests of $M$. benigna. Two male specimens of an unidentified species of Coelioxys (Megachilidae) emerged from one cell series (Table V). Also, many specimens of an unidentified phorid fly emerged from another cell series, apparently causing the death of one host bee. Two other fly species (Mycetophilidae) and one Psocoptera emerged from another $M$. benigna cell series. All host cells produced adult bees in this cell series. A large number of unidentified chalcidoid wasps (Hymenoptera) emerged from another cell series, apparently causing the death of one of the three host bees. The only nest associate found in a nest of $M$. maculata was a conopid fly that emerged from a nest containing a single unfinished cell and a dead adult female.

Table II. Cell series of two species of Megachile (Moureapis) collected in the RPPN Estação Ambiental de Peti (Minas Gerais, Brazil).

\begin{tabular}{lcccccc}
\hline Species & Ntn & $0(\mathrm{~cm})$ & $\mathrm{Nc}$ & $\mathrm{Ctn}$ & $\mathrm{Ncs}$ & $\mathrm{Ccs}$ \\
\hline M. (Moureapis) benigna & 13 & $2.3 \pm 0.4$ & 108 & $8.4 \pm 5.7$ & 30 & $3.6 \pm 1.3$ \\
M. (Moureapis) maculata & 2 & \pm 0.3 & 8 & $4.0 \pm 1.4$ & 3 & $2.7 \pm 1.5$ \\
\hline
\end{tabular}

Ntn number of trap nests occupied, 0 mean internal diameter of trap nests ( \pm standard deviation), Nc total number of cells, $C$ tn mean number of cells per trap nest ( \pm standard deviation), Ncs total number of cell series (see text for details), Ccs mean number of cells per cell series ( \pm standard deviation). Values of Ccs did not differ $(\alpha=0.05$; Dunn's test) 


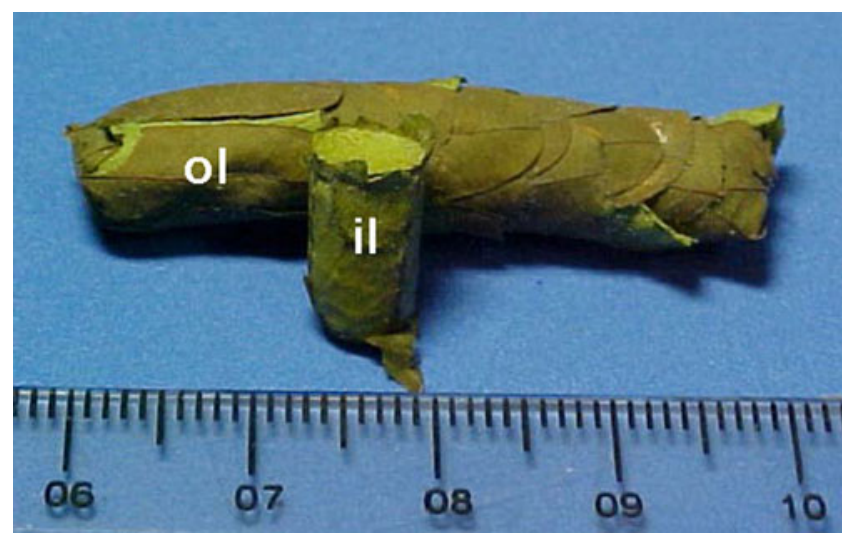

Figure 2. Part of a series of cells of Megachile (Moureapis) benigna from which the oldest one was detached. The loose outer layer $(o l)$ of this cell was removed, exposing the tight inner layer $(i l)$. Note the circular leaf cap enclosing the exposed cell. The smallest unit on the scale is equal to $1 \mathrm{~mm}$.

The percentages of cells and cell series parasitized for each species are shown in Table VI. Causes of mortality were not always obvious (Table VII). Only cases of mortality due to the attack by other organisms could be verified. Nine $M$. benigna did not emerge from their cells for unknown reasons. Two of these nine cells were infested by a saprophytic fungus (Apiocarpella sp.-Sphaeropsidales), which may have grown on the dead bees and/or food

Table III. Types of leaf material used by species of Megachile (Moureapis) in the construction of the outer layer of the cell series obtained in trap nests in the RPPN Estação Ambiental de Peti (Minas Gerais, Brazil).

\begin{tabular}{lccc}
\hline Species & $T$ & \multicolumn{2}{c}{ Employed material (\%) } \\
\cline { 2 - 4 } & & EL & LP \\
\hline $\begin{array}{l}\text { M. (Moureapis) } \\
\text { benigna }\end{array}$ & 10 & $26.4(210)$ & $73.6(408)$ \\
$\begin{array}{l}\text { M. (Moureapis) } \\
\text { maculata }\end{array}$ & 3 & $38.8(68)$ & $61.2(77)$ \\
\begin{tabular}{l} 
Totals \\
\hline
\end{tabular} & 13 & 278 & 485 \\
\hline
\end{tabular}

$T$ total number of cell series for which leaf material was analyzed. mean percentage of entire leaf or leaflets (EL) and of pieces of leaf or of leaflets (LP). The total numbers of each kind of material for each species of Megachile are between parentheses provision but which probably did not kill the bees directly.

\section{DISCUSSION}

Nests of the two species of Megachile (Moureapis) obtained in the trap nests in Peti had not been previously described and only two nests of another species in the subgenus, $M$. apicipennis Schrottky, 1902, were already known (von Ihering 1904; Laroca 1991). These two $M$. apicipennis nests, however, were so different from each other that they certainly did not belong to the same species and subgenus. In the nest described by von Ihering (1904), the cells were constructed with mud, by a bee belonging in other subgenus, such as Chrysosarus (e.g., Laroca 1971; Zillikens and Steiner 2004, Cardoso and Silveira, unpublished data). The nest illustrated and briefly described by Laroca (1991), however, conforms to the ones collected in Peti, including the fact that more than one cell series were packed side-by-side inside a bamboo culm.

The general structure of nests of Moureapis, considering those of M. benigna and M. maculata studied here and that of $M$. apicipennis presented by Laroca (1991), is the same as those described for most other Megachile (e.g., Michener 1953; Medler 1958; Krombein 1967; Laroca 1971; 
Table IV. Cell status in the nests of the species of Megachile (Moureapis) obtained in trap nests in the RPPN Estação Ambiental de Peti (Minas Gerais, Brazil).

\begin{tabular}{lccccc}
\hline Species & Cell status & & & Total number of cells \\
\cline { 2 - 4 } & Finished & Unfinished & Empty & \\
\hline M. (Moureapis) benigna & 104 & 4 & 0 & 108 \\
M. (Moureapis) maculata & 6 & 2 & 1 & 8 \\
\hline
\end{tabular}

A finished cell is one closed and provisioned or one from which a bee has emerged, an unfinished cell is an open cell with a thin "leaf wall" (just one or a few layers of leaf peaces not tightly stick together), an empty cell is a cell with no food provision (see text for explanation)

Laroca et al. 1987). The two species of $M$. (Moureapis) studied at Peti regularly used entire leaves and/or leaflets to construct their cells, as documented for some other species of Megachile (e.g., Yanega 1994; Zillikens and Steiner 2004; Raw 2007). However, these materials were used irregularly, probably due to spatial and temporal variation in the availability of convenient-sized leaves or leaflets needed by these bees. For example, M. benigna regularly used leaf fragments or leaflets to construct their brood cells in one site in April. These materials were employed by both $M$. maculata and M. benigna in December in another site along another trail. However, entire leaves or leaflets were not employed in the construction of cell series of $M$. benigna collected in the same period but approximately $40 \mathrm{~m}$ away from the previous ones.
The concentration of nesting activity by Megachile in the warm, rainy season as observed in Peti was also described for other bees in other areas of Brazil (Becker et al. 1991; Camillo et al. 1995; Oliveira 1999; Alves-dos-Santos 2003; Martins et al. 2002). Some authors (e.g., Viana et al. 2001) considered that such activity peaks are associated with food availability. No measure of seasonal fluctuation of floral resources was done in Peti. However, the period between October and March is when bees are most abundant and diverse at flowers in the region (Silveira et al., unpublished data). A comparison between the distributions of the nesting activities of the species studied here is hindered by the very small number of nests obtained of M. maculata. This may be the result of M. maculata being rarer than M. benigna in the Peti area or in the specific environment

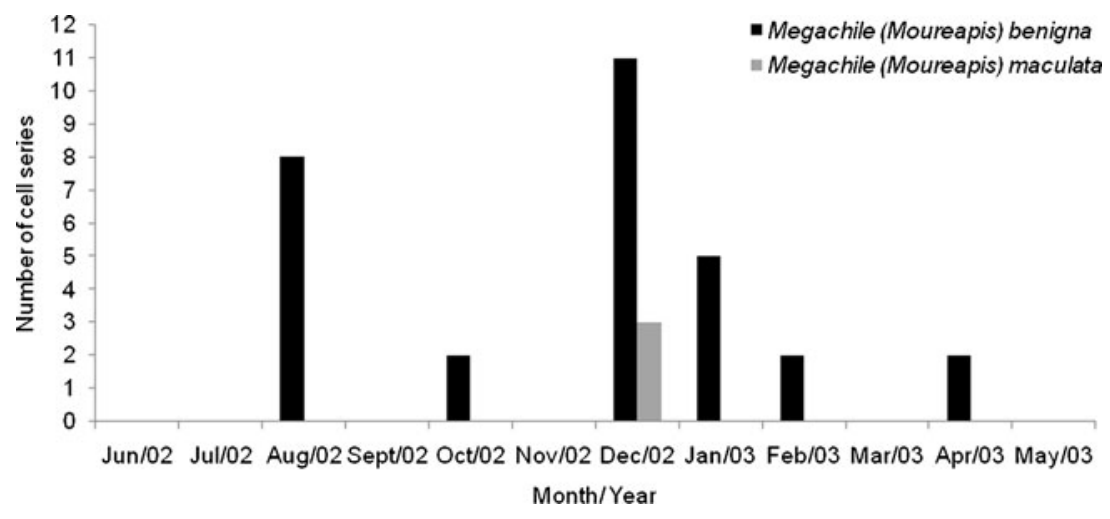

Figure 3. Nesting activity of the two species of Megachile (Moureapis) Raw obtained in trap nests in the RPPN Estação Ambiental de Peti (Minas Gerais, Brazil) along a year. 
Table V. Insects associated with cells of Megachile (Moureapis) obtained from trap nests in the RPPN Estação Ambiental de Peti (Minas Gerais, Brazil).

\begin{tabular}{|c|c|c|c|}
\hline Host species & $\mathrm{NC}$ & $\mathrm{H}$ & $\mathrm{P}$ \\
\hline \multirow[t]{4}{*}{ M. (Moureapis) maculata } & 1 & - & 1 Conopidae (Diptera) ${ }^{\mathrm{a}}$ \\
\hline & 4 & $2 \lesssim ; 2 \lesssim$ & Coelioxys sp. \\
\hline & 5 & 4 ㅇ & Phoridae (Diptera) ${ }^{\mathrm{b}}$ \\
\hline & 3 & 1 क $; 1 \hat{\jmath}$ & Chalcidoidea $^{\mathrm{b}}$ \\
\hline \multirow[t]{2}{*}{ M. (Moureapis) benigna } & & & 1 Psocoptera ${ }^{c}$ \\
\hline & 3 & 3 & $\begin{array}{l}1 \text { Mycetophilidae sp. } 1 \text { (Diptera) }{ }^{\mathrm{c}} \\
1 \text { Mycetophilidae sp. } 2 \text { (Diptera) }^{\mathrm{c}}\end{array}$ \\
\hline
\end{tabular}

Each line in front of a species name represents a different cell series constructed by females of that species. $N C$ number of cells in the cell series, $H$ and $P$ the number and sex of host bees and of parasites emerged from the series, respectively

${ }^{\text {a }}$ This fly is a parasitoid of adult bees and probably emerged from the nesting female (see text)

${ }^{\mathrm{b}}$ Many specimens

${ }^{\mathrm{c}}$ Probably commensals because all host individuals emerged from the nests

sampled. Another reason that M. maculata may not have been found very often is that this species did not prefer the size, texture, or placement of the bamboo culms. They may have been incidental in the culms, but common in other types of nesting materials.

The number of generations produced by tropical bees has been less studied than voltinism in bees from temperate zones. It seems, however, that production of one to two broods each year is common in the tropics (Roubik 1989). Sakagami and Laroca (1971), reviewing the literature on the reproduction of species of Xylocopa and Ceratina, suggested that bivoltinism is expected where there is a single pronounced dry season, such as in Peti. However, only two studies on Brazilian Megachile were found to contain data on the number of yearly generations. In one of them, the species, Megachile (Chrysosarus) pseudanthidioides was bivoltine and it was suggested (Zillikens and Steiner 2004) that this could be an adaptation to escape the cool winter when less food is available. Another study (Martins and Almeida 1994) on Megachile (Schrottkyapis) assumptionis was conducted in Belo Horizonte located about $60 \mathrm{~km}$ from Peti and under the same climatic conditions. This species seems to be univoltine, diapausing during the regional warm, rainy season. $M$. assumptionis was suggested to be a specialist in occupying abandoned nests of Ptilothrix plumata, and its

Table VI. Number $(n)$ of cell series, finished cells, and parasite infestation rates (\%) recorded for two species of Megachile (Moureapis) Raw obtained in trap nests in the RPPN Estação Ambiental de Peti (Minas Gerais, Brazil).

\begin{tabular}{|c|c|c|c|c|}
\hline \multirow[t]{2}{*}{ Host species } & \multicolumn{2}{|c|}{ Cell series } & \multicolumn{2}{|c|}{ Finished cells } \\
\hline & $n$ & $\%$ infested & $n$ & $\%$ infested \\
\hline M. (Moureapis) benigna & 30 & 10 & 104 & 3.8 \\
\hline M. (Moureapis) maculata & 3 & 0.0 & 6 & 0.0 \\
\hline All species & 33 & 9.1 & 110 & 3.6 \\
\hline
\end{tabular}


Table VII. Numbers of Megachile bees killed by different mortality agents and by unknown causes in trap nests in the RPPN Estação Ambiental de Peti (Minas Gerais, Brazil).

\begin{tabular}{lccccc}
\hline Species & \multicolumn{2}{l}{ Mortality agents } & \multirow{2}{*}{ TM (\%) $\begin{array}{c}\text { Unknown mortality } \\
\text { cause (\%) }\end{array}$} \\
\cline { 2 - 5 } & Chalcidoidea & Phoridae (Diptera) & Coelioxys spp. & \\
\hline M. (Moureapis) benigna & 1 & 1 & 2 & 3.8 & $9(8.7)$ \\
M. (Moureapis) maculata & 0 & 0 & 0 & 0 & $0(0.0)$ \\
\hline
\end{tabular}

$T M$ total ratio of mortality caused by known agents

nesting activity was correlated with availability of such nests. It also may be related to specialization on some food resources, but no information is available on this.

With only these examples, it is impossible to make any generalization on the determination of voltinism in Brazilian Megachile. Thus, explanation on why $M$. benigna is bivoltine in Peti is speculative. Although the regional cool dry season is considered to be a season of food scarcity, there are many plants, especially tree species, which flower abundantly in August-September just before the beginning of the rainy season. Thus, the second adult population of M. benigna in Peti may emerge in synchrony to this resource boom.

Despite the large space available in the trap nests used in Peti, the numbers of cells per cell series were relatively small (between one and six), as compared, for example, with up to 17 cells found by Stephen and Torchio (1961) in cell series of Megachile rotundata. Of course, in Peti, an unknown portion of the smallest cell series were collected before the nesting female had finished them. On the other hand, leaving the occupied trap nests an additional month in the field would certainly allow for many bees to emerge and leave the nests before being collected.

The sex ratio observed for $M$. benigna in Peti is compatible with values reported for other species in the genus (e.g., Krombein 1967). However, the small sample sizes do not allow for many conclusions to be taken from the data, especially in relation to $M$. maculata from which only five specimens were obtained. Moreover, it could be argued that the sex ratios obtained in this study might be biased if a relatively large proportion of incomplete cell series were collected. If this was the case, and if male cells of $M$. benigna tend to be the last to be constructed in each cell series, as is common among other species in the genus (Krombein 1967; Scott et al. 2000), then, sex ratio for this species may actually be more male biased than recorded here. However, considering the small number of unfinished cells in $M$. benigna cell series (four unfinished cells in a total of 104, Table IV), it is reasonable to consider that most of the nests were actually concluded by the bees and, thus, that the sex ratio calculated here are fair estimates of the real sex ratio of these bees in Peti.

Another issue worth rising is the potential influence of hole width on the sex ratio of progenies produced by females. It has been shown for other Megachile species that nests built in the narrowest cavities usually contain a highly malebiased progeny (e.g., Krombein 1967; Bosch and Kemp 2001). This also seems to be confirmed by the highly female-biased progeny produced by $M$. (Chrysosarus) pseudanthidioides nesting in wooden boxes, which did not limit the space for cell construction (Zillikens and Steiner 2004). However, the data obtained in Peti seem to contradict this relationship because progenies of $M$. benigna with balanced sex ratios were produced in the wide trap nests. Thus, culm diameter alone does not seem to determine the sex ratio of the progenies of $M$. benigna and nesting females seem to be able to define the diameter of their cells independently of the culm walls. This suggests adaptation by these bees to nest in relatively wide cavities. The idea that Moureapis actually may prefer to use such wide cavities is reinforced by the fact that all nests 
now known of species in this subgenus, $M$. apicipennis (Laroca 1991), M. benigna, and $M$. maculata (this study) were constructed in similar nesting substrates. This is an interesting issue, which deserves more studies.

Many of the mortality agents known to act on Megachile were recorded in the nests obtained in Peti. Of the organisms emerging from the cell series, Coelioxys spp. are known to parasitize nests of Megachile and other bee species, and chalcidoid wasps and conopid flies are known to be parasitoids of Megachile (e.g., Michener 1953; Krombein 1967; Peck 1969; Blochtein and Wittmann 1988; Woodward 1994; Morato 2003; Pitts-Singer and Cane 2011). Phorid flies are known to be both cleptoparasite and parasitoid of bees (Krombein 1967; Brown 1997; Gonzalez et al. 2002; Otterstatter et al. 2002; Wcislo et al. 2004; Brosi et al. 2006; Smith and Brown 2008) and, in the case of Peti, it is not clear if these flies fed on the brood provision or on the bee larvae themselves. The conopid fly emerged from a nest of $M$. maculata was probably responsible for the death of the adult female found in the nest, since these flies are known parasitoids of Megachile (e.g., Krombein 1967; Doroshina 1991).

Mycetophilid flies, as those emerged from a cell series of M. (Moureapis) benigna, are known to feed on fungi (Borror and DeLong 1988) and, thus, can probably be discarded as a threat to the bees. The same can be said of the Psocoptera, which also emerged from the same cell series and should not be a death agent for bees.

\section{ACKNOWLEDGMENTS}

The authors would like to express their gratitude to Alexsander A. Azevedo, Prof. Alice F. Kumagai, Gabriel M. Yazbeck, Luiz Roberto R. Faria Júnior, Nilson G. Fonseca, Roderic B. Martines and Rodrigo L. Dias (in alphabetic order) for help in field work; to Dr. Anthony Raw and Dr. Gabriel Melo for help in the identification of Megachile; to Prof. Alice F. Kumagai for the identification of the groups of some nests associates; to Gabriel M. Yazbeck for help in statistical analyses; to Dr. Ary Corrêa Junior and Danúbia Telles Braga for fungi identification; to Dr. Rosy Mary dos Santos Isaias for help with plant anatomic observations; to the Minas Gerais state energy company, CEMIG, for financial support and to the staff of the ecological station of Peti for support in the field; to two anonymous referees for their suggestions on the first version of the manuscript. This paper is dedicated to Rodrigo L. Dias, who first set the trap nests in a vain search for orchid bees...It was worthwhile, anyway!

Biologie de la nidification chez deux espèces de Megachile (Moureapis) (Hymenoptera: Megachilidae) dans une réserve de forêt semi-caducifoliée du sud-est du Brésil

Forêt atlantique / abeilles sauvages / nid / matériau / nid-trappe / bionomie

Zur Nestbiologie von zwei Megachile (Moureapis)Arten (Hymenoptera: Megachilidae)in einem Halbtrockenwald-Schutzgebiet in Südostbrasilien.

\section{Atlantischer Regenwald / Wildbienen / Bionomie / Nestmaterial / Nistfallen}

\section{REFERENCES}

Almeida, D.A., Martins, R.P., Buschini, M.L.T. (1997) Behavior and nesting dynamics of the neotropical cavity-nesting specialist bee Megachile assumptionis Schrottky, with comparisons to the neartic Megachile brevis Say (Hymenoptera: Megachilidae). J. Hymenoptera Res. 6, 344-352

Alves-dos-Santos, I. (2003) Trap-nesting bees and wasps on the University Campus in São Paulo, Southeastern Brazil (Hymenoptera: Aculeata). J. Kansas Entomol. Soc. 76, 328-334

Armbrust, E.A. (2004) Resource use and nesting behavior of Megachile prosopidis and M. chilopsidis with notes on M. discorhina (Hymenoptera: Megachilidae). J. Kansas Entomol. Soc. 77, 89-98

Ayres, M., Ayres, J.R.M., Ayres, D.L., Santos, A.S. (2005) BioEstat 4.0. Sociedade Civil Mamirauá, Belém

Barthell, J.F., Frankie, G.W., Thorp, R.W. (1998) Invader effects in a community of cavity nesting megachilid bees (Hymenoptera: Megachilidae). Environ. Entomol. 27, 240-247

Becker, P., Moure, J.S., Peralta, F.J.A. (1991) More about euglossine bees in amazonian forest fragments. Biotropica 23, 586-591

Blochtein, B., Wittmann, D. (1988) Mating site specificity, reprodution and vector selection in Nemognatha nigrotarsata (Col., Meloidea), a nest parasite of leaf- 
cutter bees and other pollinators of crops in Rio Grande do Sul. J. Appl. Entomol. 105, 414-419

Borror, D.J., DeLong, D.M. (1988) Introdução ao estudo dos insetos. Edgard Blücher, São Paulo

Bosch, J., Kemp, W.P. (2001) How to manage the blue orchard bee as an orchard pollinator. Sustainable Agriculture Network, Beltsville

Brosi, B.J., Smith-Prado, A., Gonzalez, V.H. (2006) A new wood-nesting Neocorynura (Hymenoptera: Halictidae: Augochlorini) from Costa Rica, with notes on its biology. Zootaxa 1189, 55-68

Brown, B.V. (1997) Systematics and fossil evidence of host-parasitoid relationships of Calamiscus Borgmeier (Diptera: Phoridae). J. Nat. Hist. 31, 1253-1259

Buschini, M.L.T., Rigon, J., Cordeiro, J. (2009) Plants used by Megachile (Moureapis) sp. (Hymenoptera: Megachilidae) in the provisioning of their nests. Braz. J. Biol. 69, 1187-1194

Camillo, E., Garófalo, C.A., Serrano, J.C., Muccillo, G. (1995) Diversidade e abundância sazonal de abelhas e vespas solitárias em ninhos armadilhas (Hymenoptera, Apocrita, Aculeata). Rev. Bras. Entomol. 39, 459-470

Cane, J.H., Schiffhauer, D., Kervin, L.J. (1996) Pollination, foraging, and nesting ecology of the leaf-cutting bee Megachile (Delomegachile) addenda (Hymenoptera: Megachilidae) on cranberry beds. Ann. Entomol. Soc. Am. 89, 361-367

Doroshina, L.P. (1991) Diptera, Conopidae parasites of bees in southern regions of their breeding. Zool. $\mathrm{Zh}$. 70, 54-57

Eickwort, G.C., Matthews, R.W., Carpenter, J. (1981) Observations on the nesting behavior of Megachile rubi and $M$. texana with a discussion of the significance of soil nesting in the evolution of megachilid bees (Hymenoptera: Megachilidae). J. Kansas Entomol. Soc. 54, 557-570

Genaro, J.A. (1996) Nest parasites (Coleoptera, Diptera, Hymenoptera) of some wasps and bees (Vespidae, Sphecidae, Colletidae, Megachilidae, Anthophoridae) in Cuba. Caribb. J. Sci. 32, 239-240

Gonzalez, V.H., Brown, B.V., Ospina, M. (2002) A new species of Megaselia (Diptera: Phoridae) associated with brood provisions of nests of Neocorynura (Hymenoptera: Halictidae). J. Kansas Entomol. Soc. 75, 73-79

Hobbs, G.A., Lilly, C.E. (1954) Ecology of species of Megachile Latreille in the mixed prairie region of southern Alberta with special reference to pollination of alfafa. Ecology 35, 453-462

Jenkins, D.A., Matthews, R.W. (2004) Cavity-nesting Hymenoptera in disturbed habitats of Georgia and South Carolina: nest architecture and seasonal occurrence. J. Kansas Entomol Soc. 77, 203-214

Kemp, W.P., Bosch, J. (2000) Development and emergence of the alfalfa pollinator Megachile rotundata (Hymenoptera: Megachilidae). Ann. Entomol. Soc. Am. 93, 904-911
Krombein, K.V. (1967) Trap-nesting wasps and bees: life histories, nests and associates. Smithsonian, Washington

Krombein, K.V., Norden, B.B. (1995) Notes on the behavior and taxonomy of Megachile (Xeromegachile) brimleyi Mitchell and its probable cleptoparasite, Coelioxys (Xerocoelioxys) galactiae Mitchell (Hymenoptera: Megachilidae). P. Entomol. Soc. Wash. 97, 86-89

Laroca, S. (1971) Notas sobre a nidificação de Chrysosarus tapytensis Mitchell (Hymenoptera, Apoidea). Bol. Univ. Fed. Paraná, Zool. 4, 39-44

Laroca, S. (1991) Euglossa stellfeldi: arquitetura do ninho e coexistência com Pseudocentron apicipennis em uma mesma cavidade. Acta Biol. Parana. 20, 103-108

Laroca, S., Schwartz Filho, D.L., Zanella, F.C.V. (1987) Ninho de Austromegachile habilis e notas sobre a diversidade de Megachile (Apoidea, Megachilidae) em biótopos neotropicais. Acta Biol. Parana. 16, 93-105

Martins, R.P., Almeida, D.A.O. (1994) Is the bee, Megachile assumptionis (Hymenoptera: Megachilidae), a cavity-nesting specialist? J. Insect Behav. 7, 759-765

Martins, C.F., Lima, M.F.C., Aguiar, A.J.C. (2002) Abelhas e vespas solitárias nidificantes em cavidades preexistentes na Reserva Biológica Guaribas (Mamanguape, PB): uma proposta de monitoramento. In: Garófalo, C.A., Freitas, G., Simões, Z. L.P., Bitondi, M.M.G., Tanaka, E.D., Guidugli, K., Colonello, N.A., Silva, J.E.B. (eds.) Encontro sobre abelhas 5, pp. 40-46. Ribeirão Preto, São Paulo

Medler, J.T. (1958) A note on Megachile inermis Prov. in trap-nests in Wisconsin. (Hymenoptera: Megachilidae). Can. Entomol. 90, 325-327

Michener, C.D. (1953) The biology of a leafcutter bee (Megachile brevis) and its associates. Univ. Kansas Sci. Bull. 35, 1659-1748

Michener, C.D. (2007) The bees of the world. The Johns Hopkins University Press, Baltimore

Morato, E.F. (2003) Biologia de Megachile (Austromegachile) orbiculata Mitchell (Hymenoptera, Megachilidae) em matas contínuas e fragmentos na Amazônia Central. In: Melo, A.R., Alves-dosSantos, I. (eds.) Apoidea neotropica: homenagem aos 90 anos de Jesus Santiago Moure, pp. 157-162. UNESC, Criciúma

Oliveira, M.L. (1999) Sazonalidade e horário de atividade de abelhas Euglossinae (Hymenoptera, Apidae), em florestas de terra firme na Amazônia Central. Rev. Bras. Zool. 16, 83-90

Otterstatter, M.C., Whidden, T.L., Owen, R.E. (2002) Contrasting frequencies of parasitism and host mortality among phorid and conopid parasitoids of bumble-bees. Ecol. Entomol. 27, 229-237

Peck, O. (1969) Chalcidoid (Hymenoptera) parasites of the alfafa leaf-cutter bee, Megachile rotundata, in Canada. Can. Entomol. 101, 418-422 
Peel, M.C., Finlayson, B.L., McMahon, T.A. (2007) Updated world map of the Köppen-Geiger climate classification. Hydrol. Earth Syst. Sci. 11, 1633-1644

Pitts-Singer, T.L., Cane, J.H. (2011) The alfafa leafcutting bee, Megachile rotundata: the world's most intensively managed solitary bee. Annu. Rev. Entomol. 56, 221-237

Raw, A. (1984) The nesting biology of nine species of Jamaican bees (Hymenoptera). Rev. Bras. Entomol. 28(4), 497-506

Raw, A. (1988) Nesting biology of the leaf-cutter bee Megachile centuncularis (L.) (Hymenoptera: Megachilidae) in Britain. The Entomologist 107, 52-56

Raw, A. (2007) An annotated catalogue of the leafcutter and mason bees (genus Megachile) of the Neotropics. Zootaxa 1601, 1-127

Richards, K.W. (1978) Comparisons of nesting materials used for the alfafa leafcutter bee, Megachile pacifica (Hymenoptera: Megachilidae). Can. Entomol. 110, 841-846

Roubik, D.W. (1989) Ecology and natural history of tropical bees, Cambridge Tropical Biology Series. Cambridge University, Cambridge

Sakagami, S.F., Laroca, S. (1971) Observations of the bionomies of some neotropical Xylocopinae bees, with comparative and biofaunistic notes (Hymenoptera, Anthophoridae). J. Fac. Sc. Hokkaido Univ., Ser. VI, Zool. 18, 57-127

Scott, V.L., Kelley, S.T., Strickler, K. (2000) Reproductive biology of two Coelioxys cleptoparasites in relation to their Megachile hosts (Hymenoptera: Megachilidae). Ann. Entomol. Soc. Am. 93, 941-948

Silveira, F.A., Melo, G.A.R., Almeida, E.A.B. (2002) Abelhas brasileiras: sistemática e identificação. Fernando A. Silveira, Belo Horizonte

Smith, P.T., Brown, B.V. (2008) Utility of DNA sequences for inferring phylogenetic relationships and associating morphologically dissimilar males and females of the bee-killing flies, genus Melaloncha (Diptera: Phoridae). Ann. Entomol. Soc. Am. 101, 713-721

Stephen, W.P., Torchio, P.F. (1961) Biological notes on the leaf-cutter bee, Megachile (Eutricharaea) rotundata (Fabricius). Pan-Pac. Entomol. 37, 85-93

Strickler, K., Scott, V.L., Fischer, R.L. (1996) Comparative nesting ecology of two sympatric leafcutting bees that differ in body size (Hymenoptera: Megachilidae). J. Kansas Entomol. Soc. 69, 26-44

Viana, B.F., Silva, F.O., Kleinert, A.M.P. (2001) Diversidade e sazonalidade de abelhas solitárias (Hymenoptera: Apoidea) em dunas litorâneas no nordeste do Brasil. Neotrop. Entomol. 30(245-25), 1

von Ihering, R. (1904) Biologia das abelhas solitárias do Brazil. R. Mus. Paulista 6, 461-481

Wcislo, W.T., Arneson, L., Roesch, K., Gonzalez, V., Smith, A., Fernández, H. (2004) The evolution of nocturnal behaviour in sweat bees, Megalopta genalis and M. ecuadoria (Hymenoptera: Halictidae): an escape from competitors and enemies? Biol. J. Linn. Soc. 83, 377-387

Williams, H.J., Strand, M.R., Elzen, G.W., Vinson, S.B., Merritt, S.J. (1986) Nesting behavior, nest architecture, and use of Dufour's gland lipids in nest provisioning by Megachile integra and $M$. mendica mendica (Hymenptera: Megachilidae). J. Kansas Entomol. Soc. 59, 588-597

Woodward, D.R. (1994) Predators and parasitoids of Megachile rotundata (F.) (Hymenoptera: Megachilidae), in South Australia. J. Aust. Entomol. Soc. 33, 13-15

Yanega, D. (1994) Nests and hosts of three species of megachilid bees (Hymenoptera: Apoidea: Megachilidae) from Coahuila, México. J. Kansas Entomol. Soc. 67, 415-417

Zillikens, A., Steiner, J. (2004) Nest architecture, life cycle and cleptoparasite of the neotropical leafcutting bee Megachile (Chrysosarus) pseudanthidioides Moure (Hymenoptera: Megachilidae). J. Kansas Entomol. Soc. 77, 193-202 